Padmasiri, Afr J Tradit Complement Altern Med., (2018) 15 (4): 1-12

https://doi.org/10.21010/ajtcam.v15i4.1

\title{
AN INVESTIGATION INTO UTILIZATION, BELIEFS AND PRACTICE OF INDIGENOUS MEDICINE IN SRI LANKA
}

\section{G. R. Padmasiri}

Library, University of the Visual and Performing Arts, 46, Horton Place, Colombo, Sri Lanka.

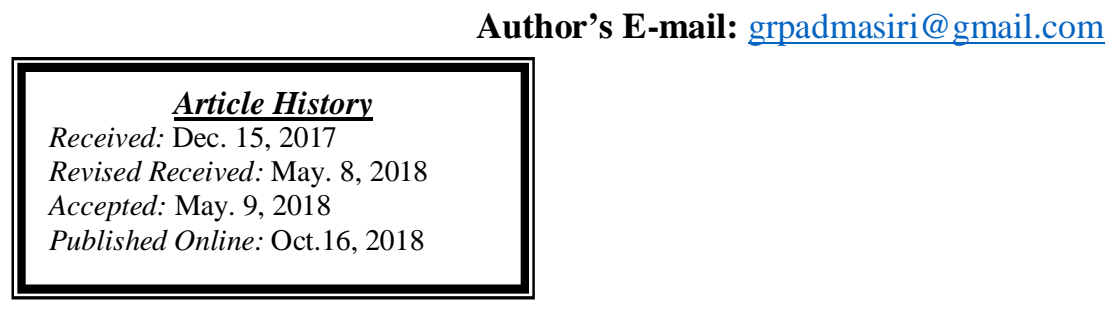

Abstract

Background: Most countries pose their own indigenous knowledge systems. Native knowledge on indigenous medicine is one of the knowledge systems widely used in many countries in Asia and Africa. In some countries, $80 \%$ of the population depend on indigenous medicine for primary health care. Sri Lanka is an island enriched with a wellestablished indigenous medical system.

Materials and Methods: The objectives of the study were to identify characteristics, usage patterns, and perceptions of communities concerning indigenous medicine. Beneficiaries of indigenous medicine were selected through purposive sampling for this study. The data were collected through a documentary survey and interviews.

Results: The study identified that the indigenous medical system of the country is called 'DeshiyaChikitsa,' 'Sinhala Vedakama,' or 'Hela Vedakama,' which encompass ritual healing practices, astrology, religious observances, and spiritual powers. Different approaches of people including the use of domestic medicine, obtaining the assistance of astrology, and rituals were identified. Regardless of age, level of education, or employment, communities trust indigenous medicine as a primary or a secondary option on the health care system of the country. The survey identified the growing demand for the indigenous medicine.

Conclusion: Around 60 to $70 \%$ of the rural population which is comprises $77.3 \%$ of total population relies on indigenous medicine. Domestic medicine, astrology and rituals associated with indigenous medicine plays a vital role in people's health care process. Experts in indigenous medicine are scattered in the country.

Key words: Indigenous Knowledge; Indigenous Medicine; Medical pluralism; Rituals; Sri Lanka

Abbreviations: LKR - Sri Lankan Rupee

\section{Introduction \\ Indigenous medicine}

Indigenous medicine is the sum total of knowledge, skills, and practices, based on the theories, beliefs, and experiences, which are strands of different cultures, whether explicable or not, used for the maintenance of health as well as for prevention, diagnosis, improvement, or treatment of physical and mental illnesses (Traditional, complementary and integrative medicine: definitions). De Wet and Ngubane (2014) recognised that indigenous medicine was in practice for thousands of years in South Africa, greatly contributing to the primary health-care at the community level, and according to the World Health Organization (2003), 80\% of the population in some Asian and African countries depend on the traditional medicine for primary healthcare.

Herbs are considered as a requisite or a primary medicinal treatment, accessible to rural communities and the urban poor (Kaniki and Mphahlele, 2002). Herbal medicines include herbs, herbal materials, herbal preparations, and finished herbal products that contain active ingredient parts of plants, or other plant materials, or combinations (Dan et al., 2010; Traditional, complementary and integrative medicine: definitions). Developed countries have now recognized the value of traditional medicine, and health care statistics demonstrate that $70-80 \%$ of the population in many developed countries depend on traditional medicine as an alternative medicine (World Health Organization, 2003). Indigenous medicine is often termed as 'traditional', 'complementary,' 'alternative,' or 'non-conventional' medicine.

Indigenous medicine is a multi-faceted knowledge system which functions alone or with religion, astrology, spiritual power, and rituals. As described by Ramcharan and Sinjela (2005), traditional medicine is a combination of herbal and spiritual elements. These treatments often include either religious observances or spiritual rites (Cho, 2004; Dan et al., 2010). Demand for traditional medical systems increased globally due to its favourable features such as cultural appropriateness, economic affordability, environmental friendly, and with fewer side-effects.Usage of multiple 
medical systems is popular in the world, and Allopathic medical system is the outspread medical system in many countries. However, traditional Chinese medical system prevailing in China and adjacent countries, and Ayurveda medical system in India, plays a vital role in the healthcare system. Similarly, in Sri Lanka, there is an increasing demand for indigenous medical system, which is closely associated with astrology and rituals including occultism. In this context, Sri Lankan people play a complex behavioral pattern in relation to the use of indigenous medicine.

\section{Sri Lanka}

Sri Lanka, officially the Democratic Socialist Republic of Sri Lanka, formerly known as Heladiva and later named as Ceylon by colonial rulers, is an island in the Indian Ocean with a total land area of 65610 square kilometres. It is a multi-ethnic and multi-religious country. The Sinhalese community forms the majority of the population (around $74.90 \%)$, while other communities include the Tamil (15.3\%), the Moors (9.30\%), and Other (0.5\%).

Sri Lanka is divided into nine provinces and twenty-five districts for administrative purposes, and each district is subdivided into several Divisional Secretariats and Gramaseva Divisions. Total population of the country is 20.2 million, consisting 9.8 million males and 10.4 million females. Rural population of the country is $77.3 \%$, urban population is $18.3 \%$, and the balance $4.4 \%$ represents the estate sector population (Department of Census and Statistics, 2014).

\section{Indigenous medical system of Sri Lanka}

The history of the indigenous system of medicine traces back to pre-Aryan civilization in the country, and as per Hansini et al. (2016), it is older than 3000 years. According to folk stories, King Ravana was a great physician who initiated the medical tradition in Sri Lanka. The indigenous medical history of the country depicts that he authored many medical books (Attygalle, 1888; Obeysekara, 2013). Currently, certain families or traditions, individuals, and communities, maintain the traditional medical knowledge system in the country. For example, the 'Horivila' tradition is well-recognized for bone setting (orthopaedics) while the 'Yatiyana' tradition is famous for treating paralysis. This knowledge is disseminated within family boundaries or to apprentices through traditional channels.

The indigenous medical system of the country is called 'Deshiya Chikitsa', 'Sinhala Vedakama', or 'Hela Vedakama', which encompasses ritual healing practices, astrology, religious observances, and spiritual powers. Experiences gained over a long period of time form the basis of this system. The history of medicine in Sri Lanka has been maintained for centuries by synthesizing several factors, some of which were unique to the country (Uragoda, 1987).

The Indian system of medicine known as 'Ayurveda' was introduced into Sri Lanka with the arrival of Prince Vijaya and his band of settlers from North India in the sixth century BC (Commission on indigenous medicine, 1947, 4). The existing medical system in the country (Hela Vedakama) was integrated with the Ayurvedic medical system when Arahath Mahinda introduced Buddhism to the country during the third century BC (Commission on indigenous medicine, 1947, 4).

The government of Sri Lanka, having recognized the value of the indigenous system of medicine, established a separate department and a ministry in 1961 and 1980 respectively, to upgrade and re-validate the indigenous system of medicine. Approximately 20,000 registered indigenous medical practitioners and over 8,000 un-registered indigenous medical practitioners function in the public healthcare service of Sri Lanka (Ministry of Health and Indigenous Medicine, 2013). A considerable proportion of the population consults both types of practitioners.

\section{Materials and Methods}

The objectives of the study were to identify characteristics, usage patterns, and perceptions of communities concerning indigenous medicine. With the consideration of exiting related literature on mixed methods and indigenous knowledge it is decided to employ mixed methods for this study. Mixed methods procedure is a popular research method in social and anthropological studies. A significant number of published research studies have incorporated mixed methods research in the social and human sciences in diverse fields such as occupational therapy (Lysack and Krefting, 1994), indigenous knowledge (Lwoga, Ngulube, and Stilwell, 2010), and preserving Aboriginal and Minority Languages (Pasch, 2008). According to Creswell (2011), this is one of the best methods to address complex problems in social and health sector, because both qualitative and quantitative analyses are involved in these spheres. Sillitoe, Dixon, and Barr (2005) recommended this approach as an effective method to investigate the inside of indigenous knowledge, and many researchers applied this method (Munyua, and Stilwell, 2010; Kiptot, 2007) to their studies on indigenous knowledge. Qualitative and quantitative methods can be integrated for different purposes to provide a more comprehensive picture of health services than either method alone (Wisdom et al., 2012).

\section{Data collection}

In the present study, out of the twenty-five administrative districts of the country, only one administrative district named as 'Gampaha District', was selected purposefully to collect data from the local community who utilised indigenous medicine. Gampaha district is located in the western province about $28 \mathrm{~km}$. away from Colombo city 
which is the main commercial hub of the country. The extent of the district is $1387 \mathrm{~km}^{2}$, and was selected due to several reasons:

Gampaha district holds the second highest population of the country, has the highest number of registered indigenous medical practitioners and a considerable number of unregistered indigenous medical practitioners, and have the socio-economic conditions which comprise urban, semi-urban, and rural communities, with various education levels and economic situations.

Through literature review, the stakeholders of indigenous medicine, i.e. 1. Indigenous medical practitioners, 2. Librarians and policy makers, 3. Recipients benefit from indigenous medicine (local community), were identified as elements of the study, and among them, only the beneficiaries of indigenous medical system was selected for this study. However, as in many cases, it is impossible for the researcher to collect or analyse all data from the entire population, owing to restrictions of time, money, and access. Therefore, the researcher had to select a representative sample consisting twenty respondents for this study.

The purposive sampling technique was employed to select the sample. This sampling technique allows the researcher to select the most appropriate population for the purpose. Interviews and a semi-structured questionnaire were mainly instrumental in data collection, whereas a documentary survey collected the background information and investigated the prevailing role of the indigenous medical system in the country. The researcher, along with a research assistant, spent around two hours per respondent to collect data. The government websites and related publications were consulted in the process of documentary survey.

All respondents extended their cooperation by allocating time for the interviews. They shared their knowledge, experiences, and views regarding the indigenous medical system without any hesitation. Information from interviews was recorded through writing notes, and the collected data were analysed and presented in a descriptive manner.

\section{Review of related literature Indigenous medicine}

Indigenous medicine plays a vital role in the healthcare sector in many countries. World Health Organization (2003) confirmed that $80 \%$ of the population in Asia and Africa depends on traditional medicine for primary health care. Recipients of indigenous medicines believe that there are no side-effects since they consist of natural resources such as plants, part of animals, minerals etc. De Wet and Ngubane (2014) describe as it is a thousand of years old knowledge system maintained by communities. Indigenous medicine is not an isolated area of knowledge, but an extended knowledge system related to religion, astrology, spiritual power, and rituals. Ramcharan and Sinjela (2005) described traditional medicine as a combination of herbal and spiritual elements. Treatments often include either religious observances or spiritual rites (Cho, 2004; Dan et al., 2010). Being culturally appropriate and environmentally with fewer side effects are some of the favourable features of indigenous medicine.

\section{Indigenous medicine in Sri Lanka}

The history of the indigenous system of medicine in Sri Lanka traces back to pre-Aryan civilization in the country. Hansini et al. (2016) claim that it is older than 3000 years, and according to folk stories, King Ravana, the author of several medical books, initiated the medical tradition in the country (Attygalle, 1888; Obeysekara, 2013). Currently, certain families or traditions, individuals, and communities, maintain the traditional medical knowledge system; e.g. the 'Horivila' tradition for bone setting (orthopaedics), the 'Yatiyana' tradition for treating paralysis.

The indigenous medical system of the country, known as 'Deshiya Chikitsa', 'Sinhala Vedakama' or 'Hela Vedakama,' encompasses ritual healing practices, astrology, religious observances, and spiritual powers. Experiences gained over a long period of time form the basis of this system. The history of medicine in Sri Lanka has been maintained for centuries by synthesizing several factors, some of which were unique to the country (Uragoda, 1987). The Indian system of medicine known as 'Ayurveda' was introduced into Sri Lanka with the arrival of Prince Vijaya and his band of settlers from North India in the sixth century BC, while the existing medical system (Hela Vedakama) was integrated with the Ayurvedic system when Arahath Mahinda introduced Buddhism to the country in the third century BC (Commission on Indigenous Medicine, 1947, 4).

\section{Results}

Information was collected only from respondents of over 30 years of age, as the researcher believes that they can select most appropriate medical system from plural medical environment of the country, which comprises allopathic medicine, homeopathy medicine, and indigenous medicine. Age distribution of the respondents was as follows: 
Table 1: Age distribution of the respondents

\begin{tabular}{|l|c|c|}
\hline Age Group (Years) & No. of respondents & Percentage \\
\hline $30-40$ & 4 & $20 \%$ \\
\hline $41-50$ & 2 & $10 \%$ \\
\hline $51-60$ & 5 & $25 \%$ \\
\hline $61-70$ & 8 & $40 \%$ \\
\hline Above 70 & 1 & $05 \%$ \\
\hline Total & $\mathbf{2 0}$ & $\mathbf{1 0 0}$ \\
\hline
\end{tabular}

It revealed that all communities use indigenous medicine without any age restriction. According to Table 1, communities in the middle age and elderly (51 -70 years) give the highest priority (65\%) for indigenous medicine.

Age distribution of the selected sample was 30 to 70 years. Their monthly income distribution was LKR $10,000.00$ to LKR 70,000.00. Only few respondents exceeded the highest amount. Education qualifications of the respondents also varied between qualifications from below General Certificate of Examination/ Ordinary Level (GCE/ OL) to Bachelor's degrees and Postgraduate qualifications. They engage in different employments in government sector and private sector, and some have retired from their occupations.

\section{Auxiliary subjects related to indigenous medicine}

Indigenous medicine is closely associated with some other subjects. Collected data from respondents and related literature in the indigenous medical system provide evidence that it is closely related to astrology, rituals, and conduct of people including food, drinks, bath, karma, etc. Indigenous medical practitioners learn about bad effects of stars and planets to the patients through astrology and then they prescribe needful before or during the period of treatments. Different types of rituals are performed with indigenous medicine, described in detail under the topic of different approaches of indigenous medicine users. It is strongly believed in indigenous medicine that personnel conduct and life style including food, drinks, bath, and behaviour, directly relates to healthy life of a person. For example, all the foods and drinks are divided into two categories, namely hot and cold, according to indigenous medical system. A person suffering from asthma should not consume food and drinks categorized as cold. Karma is one of the concepts in Hinduism and Buddhism that describe actions driven by intention, which leads to future consequences. Some people continuously suffer from incurable diseases, and no medical system can diagnose the problem. The cause of such illness is described as karma by indigenous medicine (GoldonLightHerbs, 2011).

\section{Different approaches for indigenous medicine}

Indigenous system of medicine is a multifaceted discipline in nature. It is related to many other concepts such as religion, astrology, and rituals as mentioned above. As a consequence, the survey identifies multiple approaches of recipients who attend to indigenous medicine. The following diagram (Figure 1) illustrates the multiple approaches practiced by respondents while attending indigenous medicine. 


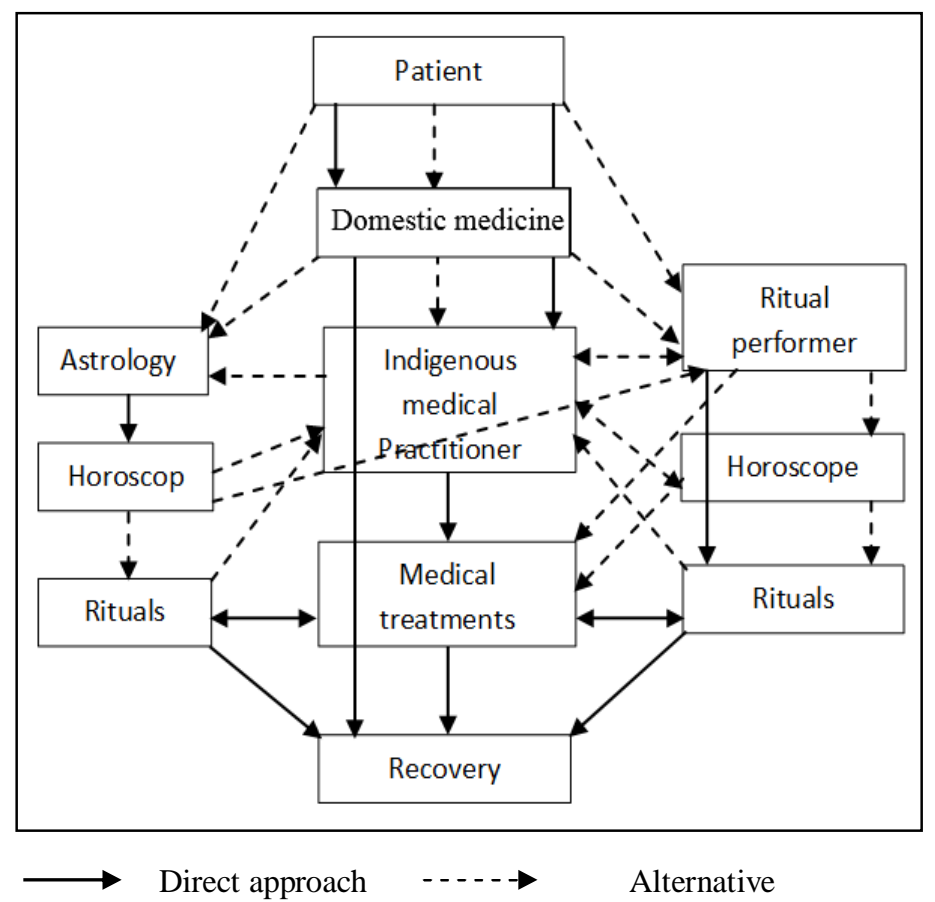

Figure 1: -Multiple approaches for indigenous medicine

\section{Domestic medicine}

The history of the indigenous system of medicine in Sri Lanka traces back to pre-Aryan civilization in the country. Knox (1681) in his book titled 'Historical account on Sri Lanka' elaborates on the indigenous medical system of the country as follows: "Here are no professed physitians [physicians] nor chyrurgeons [surgeons], but all in general have some skill that way and are physitians, and chyrurgeons to themselves." Not only in Sri Lanka, but also other countries such as China, India, Korea (Peltzer, 2009; Hariharan et al., 2014), Indonesia (Primadesi, 2012), and African countries (Msuya, 2007), possess well-established indigenous medical systems, basically in the oral form. The tacit and explicit literature concludes that each and every person in Sri Lanka, especially elders, own some knowledge on domestic medicine. Domestic medicine is referred to as home remedies, ath-beheth (medicine-at-hand), godavedakama (local healings), and paramparika vedakama (traditional medicine) in Sri Lanka.

Domestic medicine is a simply-prepared medication, use of medicinal products without prescriptions, or professional supervision or rituals. Sometimes people exercise medicines with rituals. All respondents (100\%) confirmed that they are sufficiently knowledgeable to cure simple headache with common cold and fever, diarrhoea, vomiting, stomach ache based on digesting problems, less poisoned insects or snake bites or first aids for snake bites, simple fracture and dislocating, injuries or wounds, boils and burns and chest pain. Similarly, they know how to maintain and behave at the times of infectious diseases such as chicken pox, measles, and mumps. Domestic medicine is the first step followed by most people in the country.

Table 2 below demonstrates some common domestic medicines use by the respondents. The researcher revealed that some respondents inherited Indigenous Knowledge (IK) of secret home remedies including rituals which is not shared with others.

Table 2: Domestic medicine

\begin{tabular}{|l|l|l|}
\hline Illness & Domestic medicine & $\begin{array}{l}\text { Pre-prepared indigenous } \\
\text { medicine use as first aid }\end{array}$ \\
\hline Headache, common cold and fever & Coriander + Ginger & $\begin{array}{l}\text { Medicinal oil/ Coconut oil } \\
\text { Seetharama guli (Pills) }\end{array}$ \\
\hline Diarrhoea & Coffee & \\
\hline Vomiting & Fried paddy (Vilanda) + Bee honey & $\begin{array}{l}\text { Asamodagam (Trachyspermum } \\
\text { involucratum*) sprit }\end{array}$ \\
\hline $\begin{array}{l}\text { Stomach ache based on digesting } \\
\text { problems }\end{array}$ & $\begin{array}{l}\text { Lime juice + Table salt } \\
\text { Ginger }\end{array}$ & $\begin{array}{l}\text { Asamodagam (Trachyspermum } \\
\text { involucratum*) sprit }\end{array}$ \\
\hline Snake bites & $\begin{array}{l}\text { Leaves + bark + roots of lime tree (for } \\
\text { wound), Juice of curry leaves (for drink) }\end{array}$ & \\
\hline Simple fracture and dislocating & & Medicinal oil \\
\hline
\end{tabular}




\begin{tabular}{|l|l|l|}
\hline Bleeding due to injuries & Coffee leaves + Turmeric & eg. Mahanarayana oil \\
\hline Boils and burns & Komarika (Aloe vera*) & $\begin{array}{l}\text { Tuvala thela (Home made } \\
\text { medicinal oil) }\end{array}$ \\
\hline Chest pain & $\begin{array}{l}\text { Garlic + Babila (Sida alnifoli*) }+ \\
\text { Fenugreek seeds }\end{array}$ & $\begin{array}{l}\text { Siddartha oil (Special medicinal } \\
\text { oil for chest pain) }\end{array}$ \\
\hline
\end{tabular}

* Scientific name

\section{Indigenous medical practitioner}

According to Ministry of Health and Indigenous Medicine (2013) around 20,000 registered indigenous medical practitioners and over 8,000 un-registered practitioners are in the public health care service in the country, and a considerable proportion of the population consults both type of practitioners. The survey revealed that people attend to indigenous medical practitioners seeking treatments mainly for following diseases or medical requirements as primary or secondary alternative method: Bone setting, Paralysis, Snake bites, Hepatitis, Respiratory diseases, Wounds, Rabies, Diseases on digesting system, Arthritis, Diseases on nerve system, Diabetic, Heart diseases, Cancer, Gastritis, and Thyroid.

Majority of the respondents expressed their views on selecting a medical system as follows:

"We use both western medicine and indigenous medicine. But we are not in a position to differentiate medical systems as primary and secondary in advance. Selecting the medical system depends on previous experiences, availability of well recognized medical practitioners, and condition of the medical requirement. For example, for a minor level bone fraction or a broken arm, or for Sengamalaya (Hepatitis), we attend to indigenous medical practitioners as a primary method of treatment. But in case of a serious accident with broken bones, we go to hospitals (western medical practitioners) as the primary treatment method and later attend to indigenous medical practitioners as the secondary method of treatment or for permanent cure. Same practice is carried out for paralysis and some other diseases."

Table 3 elaborates behaviour of the respondents according to the situation faced by them. People practice same method of treatment in two different ways based on the condition of the illness.

Table 3: Selecting a medical system

\begin{tabular}{|l|l|l|}
\hline Disease & Western medicine & Indigenous medicine \\
\hline Bone setting & 1,2 & 1,2 \\
\hline Paralysis & 1 & 2 \\
\hline Snake bites & 1,2 & 1,2 \\
\hline Hepatitis & 1 & 1,2 \\
\hline Respiratory diseases & 1 & 2 \\
\hline Wounds & 1,2 & 1,2 \\
\hline Rabies & 1 & 1 \\
\hline Diseases on digesting system & 1 & 1 \\
\hline Arthritis & 1 & 1,2 \\
\hline Diseases on nerve system & 1 & 2 \\
\hline Diabetic & 1,2 & 1,2 \\
\hline Heart diseases & 1 & 2 \\
\hline Cancer & 1 & 2 \\
\hline Gastritis & 1,2 & 1,2 \\
\hline Thyroid & 1 & 2 \\
\hline \multicolumn{2}{|c|}{$1-$ Primary method } & - Secondary method \\
\hline
\end{tabular}

\section{Astrology}

Astrology is the study of cosmic influences that are considered to affect all living creatures, including humans. It is an important part in indigenous medical system all over the world (Hysen, 1984). Most people in Sri Lanka, especially the Buddhists and Hindus, believe that illnesses and misfortunes they face are directly related to the influences of solar system including sun, moon, and other planets. Knox $(1861,177)$ has provided evidence for astrological knowledge of Sinhalese as follows: "Astrologers are skilful in the knowledge of the stars, and planets... they pretend to foretell all things concerning the health and recovery of sick persons." Therefore, when they suffer from continuous, long term, or incurable diseases, they visit astrologers while receiving domestic medicine or prescribed medicine by a medical practitioner. A very high percentage $(90 \%)$ of respondents follow prescribed rituals for fast recovery from their illnesses. Horoscope is the main source of information used by astrologers to make their comments or predictions over the patient. 
The survey revealed that astrologers prescribe some rituals such as wearing Yanthra (talisman - a symbolic drawing done on a copper sheet to protect the bearer from ailing evil effects caused by deities and planets), gems, pooja (alms-giving), or other rituals such as lime cutting, use of blessed water through manthra ${ }^{1}$ (incantation). Ramos (2015) identified that Filipinos also wear on their necks anting-anting or talisman objects as an act of protecting themselves from the fury of evil spirits. Primadesi (2012) describes that manthra used for healing some kind of illnesses bear its own features and language characteristics. Bali or thovil (mass-scale rituals) are also prescribed according to the planetary influences attributed to the patients and direct them to ritual performers. Some astrologers attend to perform rituals by themselves and also prescribe some medicine.

\section{Rituals}

Rituals are performed with the intention of preventing illnesses or bad influences from the solar system and spiritual bodies. Kusumaratne (2005) has identified three purposes expected by patients and indigenous medical practitioners from rituals as follows: (1) to increase the effectiveness of empirical medicine, (2) to remove the perceived bad influences of planets or demons, and (3) to protect patients from the bad influences of planets or demons. Peltzer (2009) describe these methods as spiritual therapies performed primarily without use of medication.

The researcher identified two types of rituals in relation to health care practised by people of Sri Lanka:

1. Common rituals

2. Personalized rituals

Common rituals are executed for a specific family, a community, an area, or the whole country. Overnight pirith ceremony (Buddhist pirith chanting), and Gammadu and kohomba yak kankariya are examples. Personalized rituals include overnight pirith ceremony, bali, tovil, wearing talisman or thread empowered through incantation, or consume or/ and apply blessed medicine. Knox (1681, 183-184) described Sinhalese (Sri Lankans) skills on medicine and rituals as follows: "They are oftentimes stung with venomous serpents ... but if the bite be taken in time, they can certainly cure themselves, and make nothing of it- which they perform both with herbs and charms."

Rituals again can be divided into two categories.

1. Rituals based on religion

2. Rituals based on gods, spiritual bodies

Respondents claimed that people follow various types of religious activities to find relief from illnesses. For example, the Buddhists follow pirith sutra deshanaya (pirith chanting) and bodhi pooja as religious activities. Overnight pirith ceremony is one of the most powerful religious activities followed by the Buddhists. Healthiness is one of the objectives expected from this ceremony. According to Buddhist teaching, healthiness is a supreme profit (arogya pramalabha - dhammapadaya) one can achieve. A team of Buddhist priests or laymen (teams specially prepared for the ceremony) recite all pirith sutra in Sutta pitaka (Buddhist teaching is broadly divided into three categories, namely, Sutta pitaka, Vinaya pitaka, and Abhidhamma pitaka) loudly during the overnight pirith ceremony. Ritual performers and devotees use selected pirith sutra from Sutta pitaka or verses in the sutra and seth pirith (selected pirith sutra for the purpose of blessing) as means to prevent from illnesses, improve health conditions speedily, and drive away bad effects from planetary system or/and spiritual bodies. For example, rathana sutra is used to eliminate bad influences of spiritual bodies and planets and improve health condition of devotees while angulimala sutra promotes easy delivery for pregnant women.

\section{Bodhi pooja (Worship to holy Bo tree)}

Bodhi pooja (Worship to holy Bo tree) is the most popular and widespread oldest ritual practice of Buddhists. Buddhist literature says that Gautama Buddha attained enlightenment beneath the Bo tree (Ficus religiosa) at Buddha Gaya in India. Therefore, Buddhist treat Bo tree as a sacred object. With the introduction of Buddhism to Sri Lanka, one branch of the original Bo tree at Buddha Gaya was brought to Sri Lanka and planted in Anuradhapura in the third century B.C., where it still flourishes as the oldest historical tree in the world, commemorating noble life and teaching of Gautama Buddha (Coomaraswamy, 1956). Thereafter, the Bo tree became a sacred object in any Buddhist temple. Some Bo trees planted in Sri Lanka were imported from Buddhist temples in India and others are local breeds. People worshiping the Bo tree believe that it has a spiritual power to bless them. Therefore, they offer everything, which are an offer for Lord Buddha, including drinks, food, pirikara (robes and other utilities offered for Lord Buddha), flowers, and lights to the Bo tree as it represents Lord Buddha. Some of the devotees offer special offerings, with or without consultation of indigenous medical practitioners, astrologers, or ritual performers, for relief from illnesses. Similarly, some people request healthiness from the Bo tree and make vows to offer special offerings including coconut plants,

\footnotetext{
${ }^{1}$ Manthra - words, statements, or verses recited to either cure an illness or nullify bad effects caused by people or spiritual bodies or get rid of evil eye, evil mouth, evil mind. 
cloths, gold, silver, or other valuable metal structures (e.g. miniature human figures, Bo trees) once they are cured from the illnesses.

\section{Deva pooja (Worship to Gods and Goddess)}

Worship to gods and goddess (Deva pooja) is considered as a good practice in Hinduism. In Sri Lanka, Hindus, Buddhists, and non-Buddhists perform Deva pooja. There are many gods and devils known by particular names, which people worship (Knox, 1681, 115). Two types of gods are identified in Sri Lankan culture, namely, gods in the Buddhist culture and gods in the Hindu culture. God Saman (Saman deviyo), and God Natha (Natha deviyo) are in the Buddhist culture, whereas God Ktharagama (Katharagama deviyo), God Vishnu (Vishnu deviyo), Goddess Paththini (Paththini deviyo) are in Hindu culture. There are well-established temples called "Devalaya" dedicated for the most powerful gods; i.e. Saman devalaya at Rathnapura is dedicated to God Saman, Katharagama devalaya at Katharagama is dedicated to God Katharagama, and Paththini devalaya at Nawagamuwa is dedicated to goddess Paththini.

Apart from the major temples, many temples are dedicated to the above-mentioned gods as well as for other gods throughout the country. Followers believe that the gods have spiritual power to help them in different ways including providing treasure, and blessings to have success and health (Kariyawasm, 1995). For example, many people visit temples (devalayas) dedicated to goddess Paththini with offerings after recovery from infectious diseases such as chickenpox, measles, mumps, or to recover from infertility. Some devotees perform rituals at their homes for goddess Paththini to pay their homage to her. In this context, devotees offer different types of offerings including fruits, milk rice, and sweets, and gifts of coconut plants, coins, gold, silver, or other valuable metal structures (e.g. miniature figures of a god or a human, specialized symbols, and jewelleries such as a necklace). The offering may differ according to the vows made by the devotees with or without consultation of a priest (Kapurala) of the temple or offerings prescribed by an indigenous medical practitioner, an astrologer, or a ritual performer. Some priests (Kapurala) at the temples dedicated for gods perform rituals and prescribe medicine for some illnesses. The service of a priest (Kapurala) is inherited by certain families and passes down from generation to generation according to family relationships (e.g. Father to son or brother to brother).

The Catholic Church and some of the sects associated with Christianity conduct various religious activities, seeking well-being for their devotees. The national basilica is a world-renowned church dedicated to the Virgin Mary in Sri Lanka. During its annual feast, thousands of devotees, both Catholic and non-Catholic, attend the annual healing and prayer service, held with the purpose of blessing the sick. This tradition goes back to over 70 years. Cardinal Malcolm Ranjith, the Archbishop of Colombo (2011) preached in his service that, "Only Jesus can heal our mental and physical ailments. As Catholics, always seek the sacraments of confession and communion! They are the privileges God gave us." Not only Catholics but devotees of other religions including Hindu and Islam make special offerings and prayers to seek relief from illnesses, in addition to medical treatments they receive.

\section{Alms-giving for spiritual bodies}

More than half (60\%) of respondents believe that bad influences of spiritual bodies, namely yaksha (demons) and pretha (supernatural beings), may be the cause to delay to cure or not to have the complete relief from some illnesses. Knox $(1681,115)$ has written that devils are the inflictors of sickness and misery upon Sri Lankans. Ritual performers analyse characteristics of the patients and pulse reading, and decide the appropriate ritual with or without consultation of a horoscope.

All respondents confirmed that there are some methods other than astrology that provide medicine with or without spiritual power or advice, to receive blessings from rituals. Some examples are as follows:

Nimithi (Omen) (a method of mathematical calculation or linguistic analysis of word or phrase expressed by the messenger in front of the indigenous medical practitioner in relation to ailments such as snake bite), betel reading (recognition of illness or other bad influences by analysing a sheaf of betel offered by the patient to the medical practitioner), black magic, and fortune telling. None of the respondents strongly accepted or refused these methods.

Attitudes of respondents' with regard to alms-giving for spiritual bodies can be summarized as follows:

"Rituals for alms-giving to spiritual bodies and remove their bad effects to patients is done by ritual performers called as kattandimahaththaya, kapumahaththaya, or adura. We are not in a position to accept or reject the concept of spiritual bodies and capability of ritual performers to carryout rituals perfectly. We are always confused and doubtful with these activities. However, there are large numbers of ritual performers as well as their followers all over the country. We ourselves also attend to them when the need arise."

\section{Khema}

"Khema" is one method of treatments based on rituals within the indigenous medical system used for specific diseases. Khema treatment may/ may not involve medicine. Some Khema treatments are related to astrology with the use of certain plants or herbs (Senanayake, 2006). Information about two Khema-treatment practitioners identified by respondents are as follows: 
"The first practitioner used khema treatment for patients with thyroxin problems. In this treatment, he tied a rolled piece of cotton cloth soaked in the medicinal mixture on the upper part of the patient's arm, and blessed the patient through incantation. The respondent stressed that without a doubt, the patient will be free from thyroxin problems after this treatment, without any surgery or other treatments."

The next story is about asthma. The practitioner prepared a ring (about two feet diameter) with young coconut leaves and leaves from medicinal plants. Then he blessed it with incantation and asked the patient to go through the ring. The patient should follow this treatment at least three times continuously, with one week interval for each time. The respondent described this method as an effective ritual treatment for asthma patients.

\section{Overall attitude regarding traditional medicine}

All respondents volunteered to express their views on the indigenous medical system in Sri Lanka. They emphasised that the medical system is very strong and effective. All living beings in this country depended on this indigenous medical system before the country was colonised by Europeans. Knox (1681) in his book titled 'Historical account on Sri Lanka' elaborates on the indigenous medical system of the country as follows: "Here are no professed physicians or chyrurgeons [surgeons], but all in general have some skill that way and are physicians, and chyrurgeons to themselves. "Further he added that there were skilful herbalists who can set a broken bone within one and half or two hours. As per his word ".It was set should knit by the time one might boil a pot of rice and three curries" (Knox, 1681). This system of medicine is economical and free from side effects. Up to recent times, it was totally free of charge. Even today, some practitioners provide treatments as a service. Communities of Sri Lanka are competent enough to prepare medicines using herbs. The respondents stressed that we prepare prescribed medicine or home remedies ourselves. We are able to collect substantial number of medicinal plants and other raw materials from our home gardens or nearest forests.

Finding an appropriate indigenous medical practitioner is one of the difficulties faced by the people. The answers given by all the respondents can be summarized as follows:

"There are large numbers of profound indigenous medical practitioners scattered all over the country. But there is not much publicity for all. They are hidden even in the same district or area, because most of them carry out their practice at their homes or in a small room around his/her residence. Sometimes there is no transport or other facilities to reach them. People attend to practitioners through information gathered from their family members or relatives, neighbours, or friends."

Respondents observed that the indigenous medical practitioners rarely get the assistance from paraprofessionals. They act as medical practitioners as well as dispensers. In the case of bone setting or orthopaedic treatments, practitioners have to spend a long time while other patients are waiting for medication. Conditions imposed by the indigenous medical practitioners over food, drinks and bath, and preparation of medicines, are some of the difficulties faced by them when using indigenous medicine. Only few respondents hesitate to follow astrological recommendations or rituals. At present there are sophisticated devises in health sector that can help to diagnose health conditions of a person. Majority of the indigenous medical practitioners are incompetent to use such devises to take decisions on illnesses and confirm the recovery. However, they are adequately confident to use their traditional methods.

\section{Discussion}

Indigenous medicine is a national heritage of a country where its own people have used it for generations. History of indigenous medical tradition of Sri Lanka dates back to pre-historic era of the country. This medical system is not limited to treat only for illnesses, but is a process that provides guidance to build up physical and mental fitness of a person.

Waxler-Morrison (1988) described that indigenous medical treatments consist of advice on diet, conduct, and regimen of life (including bathing, exercise, sleep, and morality) along with medicines. Thus it incorporates with other related subjects such as astrology, religion, rituals, human behaviour and conduct. Ramcharan, and Sinjela (2005) described traditional medicine as a combination of herbal and spiritual elements. Treatments often include either religious observances or spiritual rites (Cho, 2004; Dan et al., 2010). Considering the above-mentioned facts in indigenous medical systems, World Health Organization $(2002,7)$ defines indigenous medicine as, “.... including diverse health practices, approaches, knowledge, and beliefs, incorporating plant, animal, and/or mineral-based medicines, spiritual therapies, manual techniques, and exercises, applied singularly or in combination to maintain the well-being, as well as to treat, diagnose, or prevent an illness."

In Sri Lanka, a significant portion of communities trusted indigenous medical system. World Health Organization (2003) has reported that $70 \%$ - $80 \%$ people rely on indigenous medicine in developing countries. Perera 
(2012) confirmed that around 60 to $70 \%$ of the rural population relies on traditional and natural medicine for their primary health care. Bone setting, dislocation and their related deformities, hepatitis, snake bites etc. are some of the specially selected areas by communities for indigenous medicine. Respondents stressed that there is a trend to attend heart, cancer, and diabetic patients, towards indigenous medicine at present. It can be concluded that people strongly believe the correction of bone or muscle deformities, treatments for hepatitis etc. can be perfectly accomplished through indigenous medicine. Treatments for snake bite, especially in remote areas are provided by indigenous medical practitioners. Currently, people search for alternative medical treatments for diseases such as heart, cancer, diabetes etc. through indigenous medicine, as people believe that the recovery of such diseases from indigenous medicine is longlasting and with no side effects.

Indigenous medical system has an inseparable relationship with astrology. Some of the indigenous medical practitioners integrate astrological or fortune-telling service in their practice (Nordstrom, 1988). People consult astrologists with or without advice from indigenous medical practitioners. Horoscope is the main source of information which aids to predict good or bad fortune of patients.

Yalman (1964) says that an individual's horoscope helps to determine a person's fate (karmaya) and predict the past/future of his/her life. In fact most indigenous medical practitioners are learnt astrologers. They know how to interpret a horoscope and prescribe appropriate rituals. It is interesting to note that some medical practitioners serve as astrologers as well as ritual performers, while others prevent themselves from practicing anything other than medicine, though they are competent in astrology and related rituals. Some of the astrologers are skilled enough to provide medicine for specific illnesses but they are not medical practitioners, and there is no provision to register as an indigenous medical practitioner.

Rituals including religious activities, offerings for gods, and occultism are alternative or supplementary activities interrelated with indigenous medical system. Rituals are also performed to protect people from bad influences of planetary deities (graha apala), demons (yakka) who inhabit all parts of the earth and sky, and peretaya (spiritual bodies) who inhabit polluted places such as graveyards. All such parties may bring misfortune and illness unless they were propitiated (Yalman, 1964), who is concerned with rituals more than myth. According to him, rituals are meaningful and consist of logical structures. Through rituals, people and indigenous medical practitioners expect an additional power for the recovery of patients. Kusumaratne (2005) describes the purposes of rituals as follows: To increase the effectiveness of empirical medicine, to remove the perceived bad influence of planets or demons, and to protect patients from the bad influence of planets or demons. Respondents' views differ on this matter. All were entrusted with religious activities such as bodhi pooja, and special services for sick at the church of Catholics, but around $10 \%$ of the respondents refuse rituals related to astrology or occultism.

Medical pluralism, the use of multiple system of medicine including allopathy, homeopathy, Ayurveda, and indigenous medicine, is a common practice followed by communities in developed and developing countries without any distinction. In Sri Lanka, it started with the arrival of Prince Vijaya and his band from India. Before the arrival of prince Vijaya, Sri Lanka processed a well-established indigenous medical system (Hansini et al., 2016). It is believed that Indian ayurvedic medical system was introduced to Sri Lanka by Vijaya and later with the introduction of Buddhism by Arahat Mahinda in the fourth century BC (Commission on Indigenous Medicine, 1947, 4). Subsequently, both systems were amalgamated (Commission on Indigenous Medicine, 1947, 4), based on their similarities. Even today, indigenous medical practitioners emphasize that there are differences among the medical systems.

However, the survey revealed that average people are not in a position to distinguish indigenous medical system owned by the country and ayurvedic medical system, since same practitioners practice both systems together. Many researchers having an elaborate existing plural medical system in Sri Lanka consider only ayurvedic medical system and Western medical system. They simply neglected thousands of year's old indigenous medical system owned by the country. However, people practice different alternatives when they use indigenous medicine as well as other system of medicine.

Indigenous medical system in Sri Lanka concerns the promotion of humans' physical and mental healthiness and social wellbeing. Indigenous medicines are delivered either free or at a relatively low cost (Kassaye et al., 2006). Communities of the country still believe that some of the medical requirements perform more successfully by indigenous medicine than other systems of medicine practiced in the country. Nordstrom (1988) listed some of the diseases specialized by indigenous medical practitioners: fractures, poisonous snake-bites, eye diseases, hepatitis, skin diseases and boils, children's disorders, sinusitis, intestinal disorders, and stroke or paralysis.

\section{Conclusion}

Around 60 to $70 \%$ of the rural population, which comprises $77.3 \%$ of total populations, rely on indigenous medicine for their primary health-care. It is concluded that age, income distribution, or educational qualifications of the communities do not materialize the use of indigenous medicine. Indigenous medical knowledge and skills in general are embedded to the communities in the country, where such knowledge is inherited from their families and the society.

Domestic medicine plays a vital role in people's health care process. Some indigenous medical treatments are based on astrology, and rituals are common practices; this section of the indigenous medicine is called as abhichara (occultism) (Kusumaratne, 2005), which is accepted by majority of the communities. Many indigenous medical practitioners with sound knowledge and skills to recover patients from specific diseases such as asthma, hepatitis, and cancer, are scattered and hidden in the country. 
Conflict of Interest: The author has declared no conflict of interest.

\section{References}

1. Attygalle, J. (1888). Notes on Sinhalese medicine. Ceylon Medical Journal, 1: 96-99, 150-155.

2. Cho, M.O. (2004). Health care seeking behavior of Korean women with lymphedema. Nursing \& Health Sciences, 6: 149-159.

3. Commission on indigenous medicine. (1947). Report of the Commission on indigenous medicine. Report no. Sessional paper no. xxiv -1947. Colombo: Government Press.

4. Coomaraswamy, A.K. (1956). Mediaeval Sinhalese art, $2^{\text {nd }}$ ed. New York: Pantheon Books.

5. Dan, Vick, Mchombu, K. and Mosimane, A. (2010). Indigenous medicinal knowledge of the San people: indigenous knowledge for sustainable agricultural development in developing countries: Knowledge the case of farm six, northern Namibia. Information Development, 26: 129-140.

6. Department of Census and Statistics. (2014). Census of population and housing 2012. Available at: http://www.statistics.gov.lk/PopHouSat/CPH2011/Pages/Activities/Reports/CPH_2012_5Per_Rpt.pdf (accessed 15 October 2017).

7. De Wet, H. and Ngubane, S.C. (2014). Traditional herbal remedies used by women in rural community in northern Maputa land (South Africa) for the treatment of gynecology and obstetric complaints. South African Journal of Botany, 94: 129-139.

8. GoldonLightHerbs. (2011). The five causes of illnesses. Available at: http://www.goldenlightherbs.com/info/five_causes_of_illnesses.aspx (accessed 25 May 2017).

9. Hansini, K.G.D.M., Peiris, R.M. and Sakunthala, H.S. (2016). A review on the use of Tirivana gal (Quartz) based on Talpatapiliyam in the indigenous medical system of Sri Lanka. In: $9^{\text {th }}$ international research conference, Rathmalana, Sri Lanka, 8-9 September 2016, p. 178. Rathmalana: Kotelawal Defense University.

10. Hariharan, A., Mymoon, M. and Poorna, R.L. (2014). Preservation and protection of traditional knowledge - diverse documentation initiatives across the globe. Current Science, 107: 1240-1246.

11. Hysen, S. (1984). Astrology in medicine. Available at: http://www.traditionalmedicine.net.au/medastro.htm (accessed 25 May 2017)

12. Kaniki, A.M. and Mphahlele, M. F. K. (2002). Indigenous knowledge for the benefit of all: can knowledge management principles be used effectively? South African Journal of Library \& Information Science, 68: 1-15.

13. Kariyawasm, A.G.S. (1995). Buddhist ceremonies and rituals of Sri Lanka. Kandy: Buddha Dharma Education Association Inc.

14. Kassaye, K.D., Amberbir, A., Getachew, B. and Mussema, Y. (2006). A historical overview of traditional medicine practices and policy in Ethiopia. Ethiopian Journal of Health Development, 20: 127-134

15. Kiptot, E. (2007). Seeing beyond fertiliser trees. A study of a community based participatory approach to agro forestry research and dissemination in western Kenya. PhD thesis, Wageningen University and Research Centre, Netherlands.

16. Knox, R. (1681). An historical relation of the island Ceylon. London: Richard Chiswell.

17. Kusumaratne, S. (2005). Indigenous medicine in Sri Lanka: a sociological analysis. Nugegoda: Sarasavi.

18. Lwoga, E.T., Ngulube, P. and Stilwell, C. (2010). Managing indigenous knowledge for sustainable agricultural development in developing countries: knowledge management approaches in the social context. The International Information \& Library Review, 42: 174-185.

19. Lysack, C. and Krefting, L. (1994). Qualitative method in field research: an Indonesian experience in community based practice. The Occupational Therapy Journal of Research, 14: 93-111.

20. Ministry of Health and Indigenous Medicine. (2013). Information and statistics. Available at: http://www.indigenousmedimini.gov.lk/Statistics.html/ (accessed 10 October 2017).

21. Msuya, J. (2007). Challenges and opportunities in the protection and preservation of indigenous knowledge in Africa. International Review of Information Ethics, 7: 1-8.

22. Munyua, H. and Stilwell, C. (2010). A mixed qualitative-quantitative- participatory methodology: a study of the agricultural knowledge and information system (AKIS) of small-scale farmers in Kirinyaga district, Kenya. Library Management, 31: 5-18.

23. Nordstrom, C.R. (1988). Exploring pluralism-the many facts of Ayurveda. Social Science and Medicine, 27: 479-489.

24. Obeysekera, M. (2013). Sri Lankave Ravana adhirajayage samskrutika urumaya (Cultural heritage of emperor Ravana in Sri Lanka) Ja-Ela: Samanthie.

25. Pasch, T.J. (2008). Inuktitut online in nunavik: mixed-methods web-based strategies for preserving aboriginal and minority languages. PhD dissertation, University of Washington, USA. 
26. Peltzer, K. (2009). Utilization and practice of traditional/ complementary/ alternative medicine (TM/ $\mathrm{CAM} /$ ) in South Africa. African Journal of Traditional, Complementary and Alternative Medicines, 6: 175-185.

27. Perera, P.K. (2012). Current scenario of herbal medicine in Sri Lanka. ASSOCHAM, 4th annual Herbal International Summit cum Exhibition on Medicinal \& Aromatic Products, Spices and finished products(hi-MAPS), New Delhi, 14 -15 April, 2012. New Delhi, NSIC, Okhla Industrial Estate.

28. Primadesi, Y. (2012). Preserving of information value in oral tradition of Minangkabau society, West Sumatera, Indonesia. In: 5th Rizal Library International Conference, Quezon City, Philippines, 25-26 October 2012. Available at: http://rizal.lib.admu.edu.ph/2012conf/fullpaper/FINAL\%20Full\%20Paper_Primadesi.pdf. (accessed 15 August 2017).

29. Ramcharan, R. and Sinjela, M. (2005). Protecting traditional knowledge and traditional medicines of indigenous peoples through intellectual property rights: issues, challenges and strategies. International Journal on Minority and Group Eights, 12: 1-24.

30. Ramos, Chen V. (2015). Body rituals on mental health and maladaptive behavior during the prehistoric Philippines. In: Proceedings of the DLSU Research Congress Vol. 3. Manila, 2-4 March, 2015. Manila: De La Salle University.

31. Ranjith, Rev. Malcolm. (2011). Blessing for thousands physical and mental disabled at our Lady of Lanka. Available at: http://www.asianews.it/news-en/Blessing-for-thousands-physical-and-mentaldisabled-at-Our-Lady-of-Lanka-22502.html (accessed 07 September 2017).

32. Senanayake, S.G.J.N. (2006). Indigenous knowledge as a key to sustainable development. The Journal of Agricultural Services, 2: 87-94.

33. Sillitoe, P., Dixon, P. and Barr, J. (2005). Indigenous knowledge inquiries: a methodologies manual for development. East Kilbride: Department for International Development.

34. Traditional, complementary and integrative medicine: definitions. (n.d.). Available at: http://www.who.int/medicines/areas/traditional/definitions/en/.

35. Uragoda, C.G. (1987). A history of medicine in Sri Lanka: from the earliest times to 1948. Colombo: Sri Lanka Medical Association.

36. Waxler-Morrison, N.E. (1988). Plural medicine in Sri Lanka: do Ayurvedic and Western medical practices differ?. Journal of Social Science Medicine, 27: 531-544.

37. Wisdom, J.P., Cavaleri, M. A., Onwuegbuzie, A. J. and Green, C. A. (2012). Methodological reporting in qualitative, quantitative, and mixed methods health services research articles. Health service Research, 47: 721-745.

38. World Health Organization. (2003). Traditional medicine. Fact Sheet Nr. 134. Available at: http://www.who.int/mediacentre/factsheets/2003/fs134/en/ (accessed 27 May 2017).

39. World Health Organization. (2002). WHO traditional medicine strategy 2002-2005. Available at: http://www.wpro.who.int/health_technology/book_who_traditional_medicine_strategy_2002_2005.pdf (accessed 27 May 2017).

40. Yalman, N. (1964). Aspects of Religion in Indian Society. American Anthropologist, 66: 690-692. 